\title{
HRM and its Impact on Employee Happiness: An Empirical Study on Sri Lankan
} Employees

\author{
H.H.D.P.J. Opatha ${ }^{1 \times(1)}$ \\ K.I. Uresha ${ }^{2}$ (iD)
}

${ }^{1,2}$ Department of Human Resource Management, University of Sri Jayewardenepura, Sri Lanka. 'Email:poojaopatha@sjp.ac.lkTel:+94763970842

Email: ishaniuresha@sjp.ac.lkTel: +94779992167

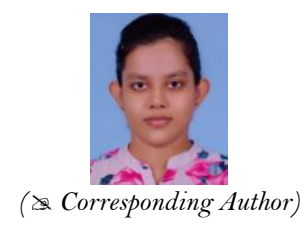

\begin{abstract}
A systematic empirical study was carried out with regard to Human Resource Management (HRM) and Employee Happiness owing to little research done, contextual gap and intellectual curiosity of authors. Objectives of the study were (1) to find the degree of happiness of Sri Lankan employees under study; (2) to find the degree of HRM practices in the organizations where employees are working under study; and (3) to investigate whether there is any positive and significant impact from HRM on employee happiness. The nature of this study was analytical; time horizon was cross sectional; and the unit of analysis was individual. A theoretical framework was formulated based on some empirical evidences in literature review and logical beliefs of the authors. Two different instruments were developed by the authors to measure the employees' happiness and HRM practice level of their organizations. Reliability and validity of the instruments are assured. Survey method was utilized and 110 employees responded to the authors developed questionnaire through the sampling technique of convenient sampling technique. The empirical findings revealed that employees' happiness and HRM practices of their organizations are in a high degree and HRM has a significant and positive impact on happiness of Sri Lankan employees under study.
\end{abstract}

Keywords: HRM, Happiness, Employee, Organization, Survey, Sri Lanka.

JEL Classification: C12 Hypothesis Testing: General.

Citation | H.H.D.P.J. Opatha; K.I. Uresha (2020). HRM and its Impact on Employee Happiness: An Empirical Study on Sri Lankan Employees. Asian Journal of Social Sciences and Management Studies, 7(2): 114-123.

History:

Received: 10 February 2020

Revised: 24 March 2020

Accepted: 27 April 2020

Published: 21 May 2020

Licensed: This work is licensed under a Creative Commons

Attribution 3.0 License (cc) EY

Publisher: Asian Online Journal Publishing Group
Acknowledgement: Both authors contributed to the conception and design of the study.

Funding: This study received no specific financial support

Competing Interests: The authors declare that they have no conflict of interests.

Transparency: The authors confirm that the manuscript is an honest, accurate, and transparent account of the study was reported; that no vital features of the study have been omitted; and that any discrepancies from the study as planned have been explained.

Ethical: This study follows all ethical practices during writing.

\section{Contents}

1. Introduction

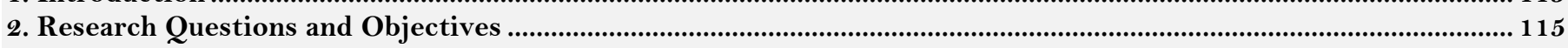

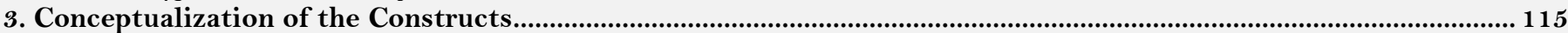

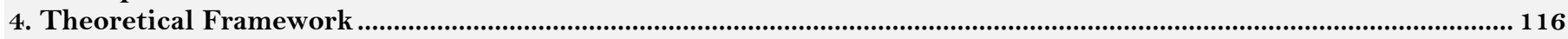

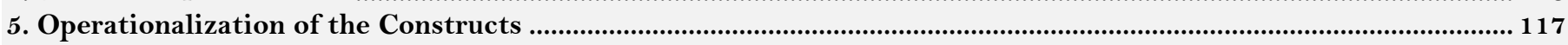

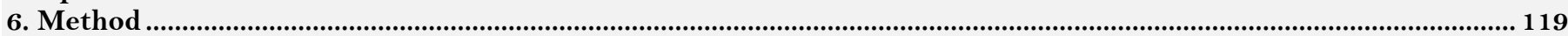

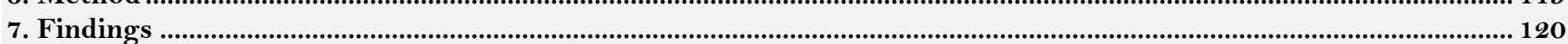

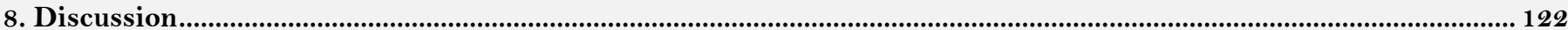

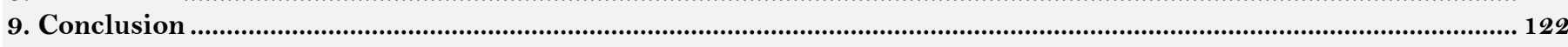

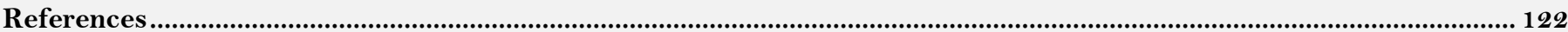




\section{Contribution of this paper to the literature}

This study adds empirical evidence in Sri Lankan context to confirm that Human Resource Management (HRM) has a significant positive impact on Employee Happiness.

\section{Introduction}

In the present turbulent business environment people are spending a busier life where many work family conflicts occur which directly affect in happiness level of people. If work family conflicts occur employees will not give their best performance in the workplace due to high stress they possess. Therefore, to gain full commitment from employees towards work, employee happiness is a major factor which human resource practitioners must concentrate in the present context. Human resource professionals have clearly identified through past research that happier employees are willing to give their best commitment towards achieving organizational objectives. Therefore, with the evolution of human resource function human resource professionals tend to concentrate on employee happiness with the purpose of developing a satisfied and committed workforce. Employee happiness has taken the lime light in the context of managing human resources as literature discloses that effective functioning of human resource function may have an impact on employee happiness which will result in achieving satisfied labour force and satisfied labour force can be considered as a key feature of generating competitive edge.

Little research has been done with regard to the impact of HRM on employee happiness in the world and no research has been done so far to test this impact of HRM on employee happiness in Sri Lankan context. Hence, a contextual gap exists in Sri Lanka regarding to the findings of degree of happiness of Sri Lankan employees and HRM practice level of organizations in Sri Lanka, and the impact of HRM on employee happiness. Furthermore, an intellectual curiosity exists to know about the impact of HRM on employee happiness and the importance of HRM practices in deciding employee happiness. Hence this study aims at filling the contextual gap on studying employee happiness with related to HRM functions.

\section{Research Questions and Objectives}

Following questions were formulated as the research questions in this study to be answered through a systematic attempt:

1. What is the degree of happiness of Sri Lankan employees under study?

2. What is the degree of HRM practices in the organizations where employees are working under study?

3. Does HRM have a significant positive impact on employee happiness?

Following objectives of the study were established by being consistent with the above mentioned research questions:

1. To find the degree of happiness of Sri Lankan employees under study.

2. To find the degree of HRM practices in the organizations where employees are working under study.

3. To investigate whether there is any positive and significant impact from HRM on employee happiness.

\section{Conceptualization of the Constructs}

\subsection{Employee Happiness}

Happiness relates to how people experience and appraise their lives in total (Bataineh, 2019). Happiness is an umbrella term for all that is good which contributes to the 'wellbeing' or 'quality of life' of both individuals and society (Veenhoven, 2012). Kaczmarek (2017) defined happiness as:

"Happiness in psychology has two references. First, happiness is an umbrella term for several theories of well-being. These theories cover intrinsically rewarding and valued experience, positive beliefs about self and the world, or positive psychological functioning. Second, happiness has been considered a basic emotion by most theorists within the psychology of emotions".

Opatha (2019) has defined happiness as a feeling of pleasure, satisfaction, or becoming pleased. According to Opatha (2019) happiness has two meanings: (1) a sense of pleasure, and (2) a profound sense of a life well lived. Overall happiness is the degree to which an individual evaluates the overall quality of his/her own life-as-a-whole positively or how much one prefers the life one lives (Veenhoven, 2017).

It is found that the people, or human capital, can provide companies with the competitive advantage through their creativeness and innovativeness (Kowalskia \& Lorettob, 2017). Supporting to enhance employee subjective and objective well-being of the employee is one of the major HR strategies in the twenty-first century (Kowalskia \& Lorettob, 2017).

\subsection{Types of Happiness}

Happiness is basically two types i.e. hedonic happiness and eudaimonic happiness. Hedonic happiness is defined as subjective wellbeing and according to Huta, Pelletier, Baxter, and Thompson (2012) there are two components for SWB which are affective component and cognitive component. According to Opatha (2019) affective hedonic happiness refers to the degree to which people can enhance pleasure over pain in their lives while cognitive hedonic happiness refers to the degree to which people are satisfied with their overall life (Global Life Satisfaction) and degree to which people have positive feelings about various domains (work, family, social, educational, religious etc.) of their lives (Dimensional Life Satisfaction). Eudaimonic happiness derives from one's living according to virtues and self-fulfilment (Opatha, 2019).

According to Veenhoven (2012) components of happiness are referred to as 'hedonic level of affect' and 'contentment'. Hedonic level of affect is the degree to which someone experiences various moods and emotions which are pleasant in character while contentment is the degree to which an individual perceives his/her aspirations are met (Veenhoven, 2012).

Following working definition which is also labeled as nominal definition was developed for the construct, i.e. happiness:

"Happiness is the sense of joyfulness and meaningfulness relating to various aspects (Eg; work, family, social, educational, religious etc.) of an individual's life." 


\subsection{HRM}

Human resource management (HRM) has become one of the most critical functional fields in an organization as it mainly focuses on the most unique resource; human beings. HRM contributes towards business development (Arachchige \& Robertson, 2015). Marescaux, Winne, and Forrier (2018) state that, sound HRM gives a signal to the employees implying that organization value and care about their wellbeing, development and contribution. Opatha (2009) provides an overall definition about HRM with related to the strategic perspective of the organization. He defines HRM as; "Effective and efficient utilization of human resources to achieve goals of an organization". One of the most used definition to have a comprehensive idea on HRM is Armstrong's definition. Armstrong's definition is explained in Eneh and Awara (2016) as; "a strategic and coherent approach to the management of an organization's most valued assets-the people working there who individually and collectively contribute to the achievement of its objectives". Wilton (2016) provides a definition on HRM from industrial perspective as; HRM refers to the context of management of principals, strategies and activities that occur between employer and employees. HRM is a distinctive perspective of employment management aims at achieving competitive advantage using cultural, personal and structural approaches through strategic utilization of fully dedicated and competent workforce (Storey, 2007).

\subsection{Human Resource Functions}

Human resource management can be viewed as an approach to precisely handle the labor force (Guest, 1987). Human resource management considered as a critical function among other organizational functions due to its unique nature as it focusses on managing an exclusive resource which is completely different than other resources.

Therefore, it is important to have a comprehensive idea on human resource management functions. Human resource management functions are sub areas or practices conducted under human resource management. Opatha (2009) has stated 18 extensive human resource management functions namely; job design, job analysis, human resource planning, recruitment, selection, hiring, induction, performance evaluation, training and development, career management, pay management, welfare management, management of incentives, employee movements, health and safety management, discipline management, grievance handling and labour relations.

Many other authors have stated about these functions having various perspectives. According to Ahammad (2017) Human resource management aims at; learning and development, recruitment and selection, professional development, performance appraisal, benefits and compensation, ensure legal compliance, equality and diversity and strategic HR. Human resourcing, managing performance appraisal, personal training and development, compensation/ reward management, personnel relations and other administrative functions such as health and safety, pensions, personal information systems are identified as HRM functions by Itika (2011).

Tubey, Rotich, and Kurgat (2015) state that, HR department basically responsible for functioning number of activities including main activities such as; recruitment, training and development, performance appraisal, rewarding and industrial relations. Moreover, Obedgiu (2017) lists down functions of HRM as aligning human resource and business strategy, listening and responding to employees, re-engineering organization process and managing transformation and change. He further states that in practice HRM mainly involves in attracting and selecting right employees through recruitment process, hiring employees, providing them with training and development during their time period of occupation, evaluating employee talent through performance appraisal and rewarding employees based on their talent.

Anthonia and Omotayo (2012) found out that, recruitment, selection, training and development are some main activities done under HRM and organizations tend to outsource these HRM functions in the present business context. HRM consists with distinctive broad functions namely; personal resourcing, managing performance, managing rewards, human resource development and employment relations as well as supportive functions such as health and safety, employee wellbeing, equality and diversity management (Wilton, 2016).

Finally, these HRM functions play a primary role in enhancing organizational performance through uplifting human capital to reach pre-determined organizational goals. Following working definition or nominal definition was developed for the construct, i.e. HRM:

"HRM is about managing employees in a way that achieving the organizational goals and employees' goals productively."

\section{Theoretical Framework}

It is said that a happy employee will become a productive employee (Joo \& Lee, 2017). HRM has to play a significant role in terms of maintaining the satisfaction of employees as it ultimately affects to the customer satisfaction. Employee satisfaction is a distinct measurement which relates to the way an organization develops their culture, pay systems, employee services, jobs and duties etc. Sankar (2019). Relevant employee, relevant manager and relevant HR department are mainly responsible for the happiness of employees (Opatha, 2019). There are some researches that have been done on HRM practices and its relationship with employee work happiness.

Providing happiness education, providing happiness counselling, promoting job satisfaction, generating and enhancing job involvement and organizational citizenship behavior, promoting personal character, adopting Maslow's theory of motivation and promoting appropriate personality traits are some major strategies available for HR departments to maintain and enhance employee happiness (Opatha, 2019). Shen (2010) has identified that the levels of employees' satisfaction with performance appraisals, staffing and pay were between high and moderate, level of satisfaction regarding to training and development was low and employees' satisfaction levels with HRM vary according to personal characteristics such as gender, age, education, position, working years, and registration status. Zamanana et al. (2020) found that HRM practices and employees' satisfaction have negative effects on intension to leave and employees' satisfaction partially mediates the relationship between HRM practices and intension to leave. Perera (2019) found that job satisfaction of employees significantly mediates the relationship between occupational health and safety practices and job performance which are some functions of HRM.

Strategic HRM is an extended part of human resource management where more concern has been given to the consistency between HRM strategies and organizational goals and objectives. The strategic human resource 
management (SHRM) mainly focuses on achieving competitive advantage by developing core competencies of the firm's human resources and integrating the HRM strategies with firm's strategies in order to pursuit of growth, profit and sustainability (Blackman, O'Flynn, \& Mishra, 2010). Blackman et al. (2010) has identified the role of strategic human resources management (SHRM) in the development of 'Gross National Happiness' (GNH) in Bhutan.

Work-life balance has been viewed as a crucial factor for both organizations and people, because it is found that work life balance greatly contributes on improving productivity of employees which in turn contributes to enhance the performance of organizations from a considerable degree (Guthrie, 2012). When work-life Balance of people is in a high state it is a major reason for them to spend their lives in a more positive, happy, healthy and successful way (Bataineh, 2019). Sustainable HRM mainly concerned with planet related matters (Green HRM), society related matters (Social HRM) and profit related matters (Economic HRM) and work life balance is a component coming under social HRM (Opatha, 2019). Thus, it can be identified that well management of human resources for sustainability contributes to improve work-life balance of employees and ultimately this increases the happiness of employees.

One of the major functions of HRM is compensation management which is consisted of pay management, incentive management and welfare management (Opatha, 2009). According to a longitudinal research done by Maleka, Swarts, and Mmako (2018) have found that participants have rated the positive emotions negatively, and they have rated the job-related wellbeing, affective commitment, employee engagement and distributive justice items positively. The dimensions of happiness index of which they have used are positive emotions, job-related wellbeing, affective commitment, employee engagement and distributive justice. The reason for the respondents to rate positive emotions as negative are that they were dissatisfied with their remuneration. The implication of this study for HR policymakers is that they must review their remuneration policy and practices and need to implement compensation management effectively and efficiently (Maleka et al., 2018). This implication ultimately implies that sound HRM in which compensation management is a major function leads employees to possess with positive emotions.

In hedonic tradition, psychologists have concentrated on the assessment of "subjective well-being", which consists of three elements: (i) life satisfaction; (ii) the presence of positive mood; and (iii) the absence of negative mood and all this together is summarized as happiness as in Zižek, Potočnik, and Vaner (2012). In human resource management, there are series of functional strategies for each HRM function that consistency with the firm's goals. Execution of these strategies leads the organizations to create competitive advantage while increasing motivation, improving employees' health, better interacting relationships, better teamwork, and also make a positive impact on the performance of the organization, individuals' subjective and objective well-being and happiness (Zižek et al., 2012).

Thus, based on the above empirical evidences and logical beliefs of the researchers, it is possible to formulate an alternative hypothesis which is stated below. Relevant null hypothesis follows the alternative hypothesis.

Alternative Hypothesis: There is a significant positive impact from HRM on employee happiness.

Null Hypothesis: There is no significant positive impact from HRM on employee happiness.

Theoretical framework is depicted in Figure 1.

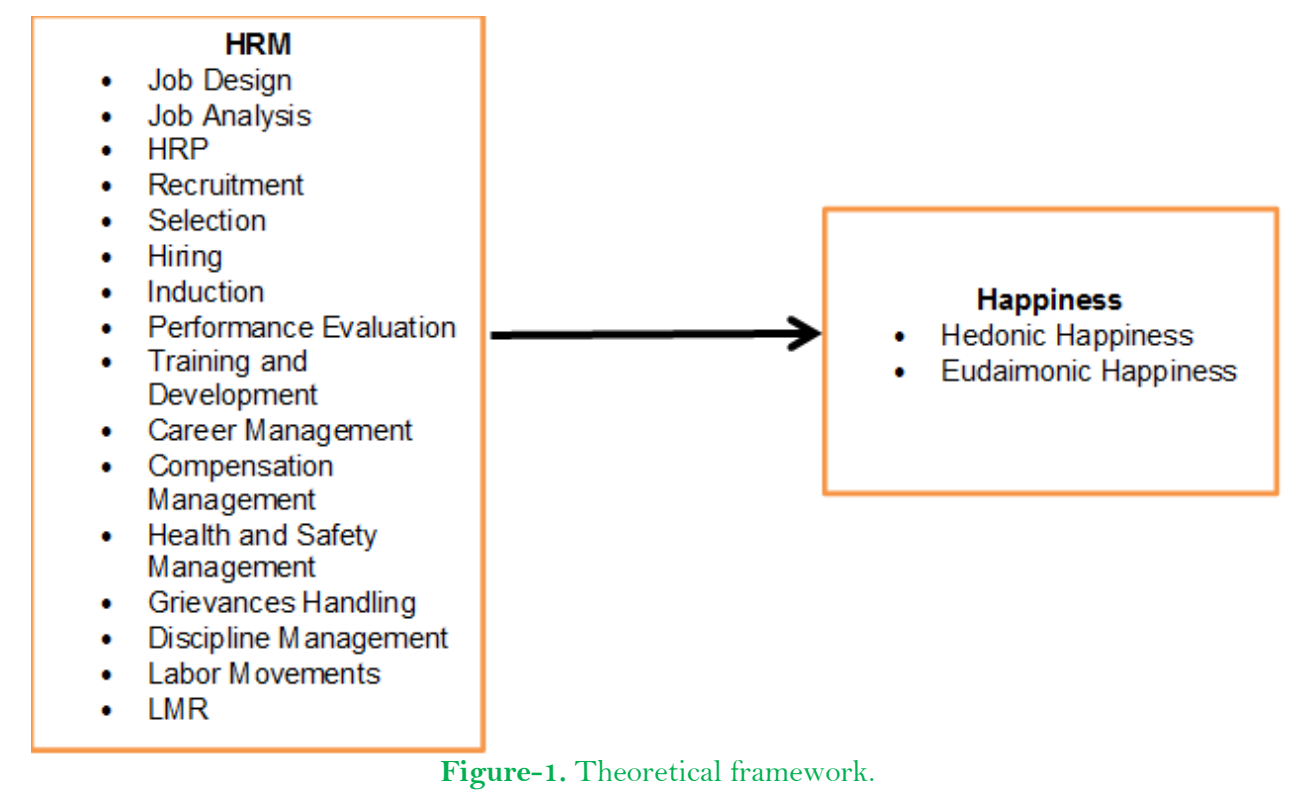

\section{Operationalization of the Constructs}

\subsection{Employee Happiness}

According to Veenhoven (2017) there are three kinds of happiness: 1) overall happiness, also called 'lifesatisfaction, 2) affective component called 'hedonic level of affect' and 3) cognitive component called 'contentment' and all these kinds of happiness can be measured using single direct questions, such as the examples below.

- Overall Happiness: "How do you feel about your life as a whole...?"

- Affective Happiness Component: "How is your mood these days...?"

- Cognitive Happiness Component: "How do you feel about what you have accomplished in your life...?"

Opatha (2019) has identified two types of happiness: 1) hedonic happiness and 2) eudaimonic happiness. These are explained under the conceptualization of constructs. Further he has mentioned that hedonic happiness is represented by pleasant life (devoted to pursuit of positive emotions) while eudaimonic happiness is represented by good life (devoted to pursuit of engagement) and meaningful life (devoted to pursuit of service to others). As per Seligman (2011) there are three elements for happiness under the original theory of authentic happiness: 1) positive 
emotions, 2) engagement and, 3) meaning and under the well being theory there are five elements: 1) positive emotions, 2) engagement, 3) relationships, 4) meaning and purpose and, 5) accomplishment.

Considering the above dimensions of happiness and happiness questionnaires developed by Lyubomirsky and Lepper (1999); Hills and Argyle (2002) (Oxford Happiness Questionnaire), Opatha (2019) authors developed statements for the questionnaire to measure happiness under the following dimensions and indicators in Table 1.

\begin{tabular}{|c|c|c|}
\hline Dimension & Indicator & Statement \\
\hline \multirow[t]{11}{*}{$\begin{array}{l}\text { Hedonic Happiness } \\
\text { (Pleasant Life) }\end{array}$} & \multirow[t]{5}{*}{ Affective Hedonic Happiness } & $\begin{array}{l}\text { I often feel joy, contented and fortunate in my } \\
\text { life rather feeling sadness, disgust and anger. }\end{array}$ \\
\hline & & I often experience cheerful and good moods. \\
\hline & & I feel that life is very rewarding to me. \\
\hline & & I feel pleased with the way I am. \\
\hline & & I often wake up with a fresh mood. \\
\hline & \multicolumn{2}{|l|}{ Cognitive Hedonic Happiness } \\
\hline & - $\quad$ Global Life Satisfaction & I am well satisfied about everything in my life. \\
\hline & \multirow{4}{*}{$\begin{array}{ll} & \text { Dimensional } \\
\text { Satisfaction }\end{array}$} & I am highly satisfied with my job. \\
\hline & & $\begin{array}{l}\text { My marriage/personal life makes me happy } \\
\text { honestly. }\end{array}$ \\
\hline & & I do exercises and I am very healthy. \\
\hline & & I am a good follower of my religion. \\
\hline \multirow{10}{*}{$\begin{array}{l}\text { Eudaimonic Happiness } \\
\text { (Good Life and } \\
\text { Meaningful Life) }\end{array}$} & \multirow{5}{*}{$\begin{array}{l}\text { Engagement and Accomplishment } \\
\text { (Good Life) }\end{array}$} & I have a sense of direction in my life. \\
\hline & & I am fully engaged with my works. \\
\hline & & I feel good when making ethical decisions. \\
\hline & & $\begin{array}{l}\text { I feel sense of improvement or expansion over } \\
\text { time. }\end{array}$ \\
\hline & & $\begin{array}{l}\text { There is a gap between what I would like to do } \\
\text { and what I have done. }\end{array}$ \\
\hline & \multirow[t]{5}{*}{$\begin{array}{l}\text { Relationships and Meaning and } \\
\text { Purpose (Meaningful life) }\end{array}$} & $\begin{array}{l}\text { I have very warm feelings towards almost } \\
\text { everyone. }\end{array}$ \\
\hline & & I do have fun with other people. \\
\hline & & $\begin{array}{l}\text { I do have a particular sense of meaning and } \\
\text { purpose in my life. }\end{array}$ \\
\hline & & $\begin{array}{l}\text { I have a sense of feeling that I have served more } \\
\text { to the society. }\end{array}$ \\
\hline & & I am very happy with what I have done. \\
\hline
\end{tabular}

The level of the instrument was interval and the summated rating received on a 20-item, 5-point Likert scale of happiness was the relevant operational definition. With regard to each of the statement mentioned above, respondents were asked to rate on a 5-point Likert scale, and the act of transforming into a different variable (with new values from 1 to 5) was done after calculating the composite indexing. The transforming was done by using the following points scale:

Points

$20-36 \quad-$ Very low level of happiness

$37-52 \quad$ - Low level of happiness

$53-68$ - Moderate level of happiness

$69-84 \quad$ - High level of happiness

$85-100$ - Very high level of happiness

\subsection{HRM}

Human resource management plays a critical role in determining the level of happiness possessed by an individual. Therefore, measuring human resource practices are important in determining the way to happiness. As mentioned by Kottawatta (2015) according to literature, number of measures are being considered in measuring human resource practices and most importantly those variables are different from one to another.

Different authors have identified various dimensions and indicators to measure Human resource management. Considering Opatha (2009) and Kottawatta (2015) Table 2 shows the indicators, dimensions and statement for each indicator for measuring HRM.

Above mentioned statements are authors developed statements referring to few studies such as; Demo, Neiva, Nunes, and Rozzett (2012); Mabaso (2012); Hirschi, Freund, and Herrmann (2013); Chaubey and Rawat (2016); Itang (2015); Biggs, Swailes, and Baker (2016) and Gomathi (2014).

The level of the instrument was interval and the summated rating received on a 18-item, 5-point Likert scale of HRM was the relevant operational definition. With regard to each of the statement mentioned above, respondents were asked to rate on a 5-point Likert scale, and the act of transforming into a different variable (with new values from 1 to 5) was done after calculating the composite indexing. The transforming was done by using the following points scale:

Points

$18-32.4-$ Very low level of HRM practices.

32.5 - 46.8 - Low level of HRM practices.

$46.9-61.2$ - Moderate level of HRM practices.

$61.3-75.6$ - High level of HRM practices.

$75.7-90 \quad$ - Very high level of HRM practices. 
Table-2. Statements for Each Dimension and Indicator for Measuring HRM

\begin{tabular}{|c|c|c|}
\hline Dimension & Indicator & Statement \\
\hline \multirow[t]{3}{*}{$\begin{array}{l}\text { Employment } \\
\text { Planning }\end{array}$} & Job Design & $\begin{array}{l}\text { My job is highly enriched (I have the ability to plan, do, and control } \\
\text { my job). }\end{array}$ \\
\hline & Job Analysis & I know clearly what duties need to be performed by myself. \\
\hline & HRP & $\begin{array}{l}\text { HR department of my organization analyzes future employee demand } \\
\text { and supply yearly. }\end{array}$ \\
\hline \multirow[t]{4}{*}{ Staffing } & Recruitment & $\begin{array}{l}\text { The organization I work for widely disseminates information about } \\
\text { both external and internal recruitment processes. }\end{array}$ \\
\hline & Selection & $\begin{array}{l}\text { The organization I work for uses various selection instruments (e.g. } \\
\text { interviews, tests, etc). }\end{array}$ \\
\hline & Hiring & $\begin{array}{l}\text { Appointment letter given by my organization when hiring an } \\
\text { employee contains all the necessary information in a detailed way. }\end{array}$ \\
\hline & Induction & $\begin{array}{l}\text { Induction training programs in my organization provide an excellent } \\
\text { opportunity for newcomers to learn comprehensively about the } \\
\text { company, job and people in the organization. }\end{array}$ \\
\hline \multirow[t]{3}{*}{$\begin{array}{l}\text { Human Resource } \\
\text { Development }\end{array}$} & Performance Evaluation & $\begin{array}{l}\text { The organization I work for periodically conducts competency-based } \\
\text { performance appraisals and disseminates results to its employees. }\end{array}$ \\
\hline & $\begin{array}{l}\text { Training } \\
\text { Development }\end{array}$ & $\begin{array}{l}\text { The organization I work for invests in my development and } \\
\text { education, promoting my personal and professional growth in a broad } \\
\text { manner. }\end{array}$ \\
\hline & Career Management & $\begin{array}{l}\text { HR Department of my organization provides career counselling and } \\
\text { career education for its employees to develop their future career plans } \\
\text { and goals. }\end{array}$ \\
\hline \multirow[t]{3}{*}{$\begin{array}{l}\text { Rewards } \\
\text { Management }\end{array}$} & Pay Management & $\begin{array}{l}\text { The organization I work for offers me a fair salary that is compatible } \\
\text { with my skills, training, and education. }\end{array}$ \\
\hline & Incentive Management & $\begin{array}{l}\text { In the organization where I work, I get incentives such as promotions, } \\
\text { commissioned functions, awards, bonuses, etc. }\end{array}$ \\
\hline & Welfare Management & $\begin{array}{l}\text { The organization I work for provides various welfare facilities like } \\
\text { medical facilities, transportation facilities, feeding facilities, loan } \\
\text { facilities etc. }\end{array}$ \\
\hline \multirow[t]{5}{*}{$\begin{array}{l}\text { Employee \& Labor } \\
\text { Relations }\end{array}$} & Employee Movements & $\begin{array}{l}\text { Employee movements such as promotions, transfers etc. are not } \\
\text { encouraged by personal biasness and favoritism but by performance of } \\
\text { employees in my organization. }\end{array}$ \\
\hline & $\begin{array}{l}\text { Health and Safety } \\
\text { Management }\end{array}$ & $\begin{array}{l}\text { The organization I work for has programs or processes that help } \\
\text { employees to cope up with hazardous incidents and prevent workplace } \\
\text { accidents. }\end{array}$ \\
\hline & Discipline Management & $\begin{array}{l}\text { HR Department implements preventive and corrective disciplinary } \\
\text { procedures to maintain the discipline of employees. }\end{array}$ \\
\hline & Grievance handling & $\begin{array}{l}\text { In my organization, there are methods to identify the root causes of } \\
\text { the grievances of employees and provides suitable solutions. }\end{array}$ \\
\hline & Labour Relations & $\begin{array}{l}\text { A culture of harmonious working relationships is encouraged in my } \\
\text { organization. }\end{array}$ \\
\hline
\end{tabular}

\subsection{Validity and Reliability of the Instruments}

\subsubsection{Reliability}

The inter item reliability of the two instruments was examined with Cronbach's Alpha test. The results of the Cronbach's Alpha test are depicted below in Table 3. Cronbach's Alpha coefficient of each instrument is greater than 0.7 which means that internal reliability of each instrument is good.

\begin{tabular}{l|c}
\multicolumn{2}{c}{ Table-3. Results of Cronbach's Alpha. } \\
\hline Instrument & Cronbach's Alpha \\
\hline Employee Happiness & .899 \\
\hline HRM & .929 \\
\hline
\end{tabular}

As per the above results we can say that the consistencies of respondents' responses to all the items in the measure are assured.

\subsubsection{Validity}

A major type of validity which is a property of an instrument is content validity that is an essential type of validity which is the extent to which the instrument measures what it intends to measure (Opatha \& Opatha, 2020). Content validity of the instrument was ensured by the conceptualization and operationalization of the variables in literature and indirectly by the high internal consistency reliability of the instruments as denoted by Alphas. As there were 20 items to test the employee happiness which is the dependent variable and 18 items to test the HRM practices which is the independent variable covering all the dimensions and indicators, it ensures that the measures include an adequate and representative set of items that would tap the concepts.

\section{Method}

In order to find answers for the three research questions a systematic survey was carried out. The survey was composed of a self-administered questionnaire that contained the two instruments developed by the authors to measure the two constructs, i.e. employee happiness and HRM.

Data collection of this study carried out through a google form where 110 responses were received around the country. Data was collected from both executive and non-executive employees in different industries categorized under manufacturing, service and other. Majority of the respondents represent nonexecutive category and when 
consider the industry larger proportion depicts service industry and then manufacturing and other industries respectively. Further, respondents around the country participated for this study where respondents around 8 districts have participated in data collection but the majority represents the Colombo district.

\section{Findings}

Under the findings of the study the derived results from the univariate and bivariate analyses are present below. Descriptive statistics were carried out under univariate analysis while linear regression analysis was carried out under bivariate analysis.

\subsection{Employee Happiness}

According to the collected data from 110 Sri Lankan employees, Table 4 presents descriptive statistics of the dependent variable of the study, i.e. employee happiness.

Table-4. Descriptive Statistics of Employee Happiness.

\begin{tabular}{|c|c|}
\hline $\begin{array}{llll}\text { Central } & \text { Tendency } & \text { and } & \text { Dispersion } \\
\text { Measures } & & & \\
\end{array}$ & Value \\
\hline Mean & 3.8545 \\
\hline Median & 4.0000 \\
\hline Mode & 4.00 \\
\hline Standard Deviation & .78794 \\
\hline Variance & .621 \\
\hline Minimum & 2 \\
\hline Maximum & 5 \\
\hline Range & 3 \\
\hline
\end{tabular}

According to the Table 4 that gives the relevant measure of central tendency, i.e the mean, it is 3.8545 which means that majority of Sri Lankan employees under the study are individuals with high level of happiness as the mean value is nearly 4 (in this study data were coded as, $1=$ very low degree, $2=$ low degree, $3=$ moderate degree, $4=$ high degree and $5=$ very high degree). The standard deviation is .78 which is less than 1 . Hence the data is not dispersed from the mean value very much and most of the employees are centered around the mean value. Table 5 provides the frequencies of employee happiness.

Table-5. Frequencies of Employee Happiness

\begin{tabular}{c|c|c|c|c}
\multicolumn{5}{c}{ Table-5. Frequencies of Employee Happiness. } \\
\hline Value & Frequency & Percent & Valid Percent & Cumulative Percent \\
\hline Valid 2 & 3 & 2.7 & 2.7 & 2.7 \\
\hline 3 & 24 & 30.9 & 30.9 & 33.6 \\
\hline 4 & 49 & 44.5 & 44.5 & 78.2 \\
\hline 5 & 24 & 21.8 & 21.8 & 100.0 \\
\hline Total & 110 & 100.0 & 100.0 & \\
\hline
\end{tabular}

Table 5 presents mainly four rows: the first row that is for the composite response low employee happiness (coded in the data with the value 2 ), the second row that is for the composite response moderate employee happiness (coded in the data with the value 3 ), the third row for the composite response high employee happiness (coded with the value 4), and the fourth row for the composite response very high employee happiness (coded with the value 5). There are 24 employees who possess moderate employee happiness and the percentage of such employees is 30.9. 49 employees possess high happiness and as a percentage it is 44.5 which is the highest frequency while 24 employees possess very high degree of happiness. Only 3 employees are in low happiness level and there are no employees who have very low level of happiness. As an overview we can say that more than a half of Sri Lankan employees (66.3\%) under study are happy or very happy individuals. The relevant histogram for the above results is depicted below in Figure 2.

Above analysis results answered the first research question of the study is: What is the degree of Sri Lankan employees' happiness under study?

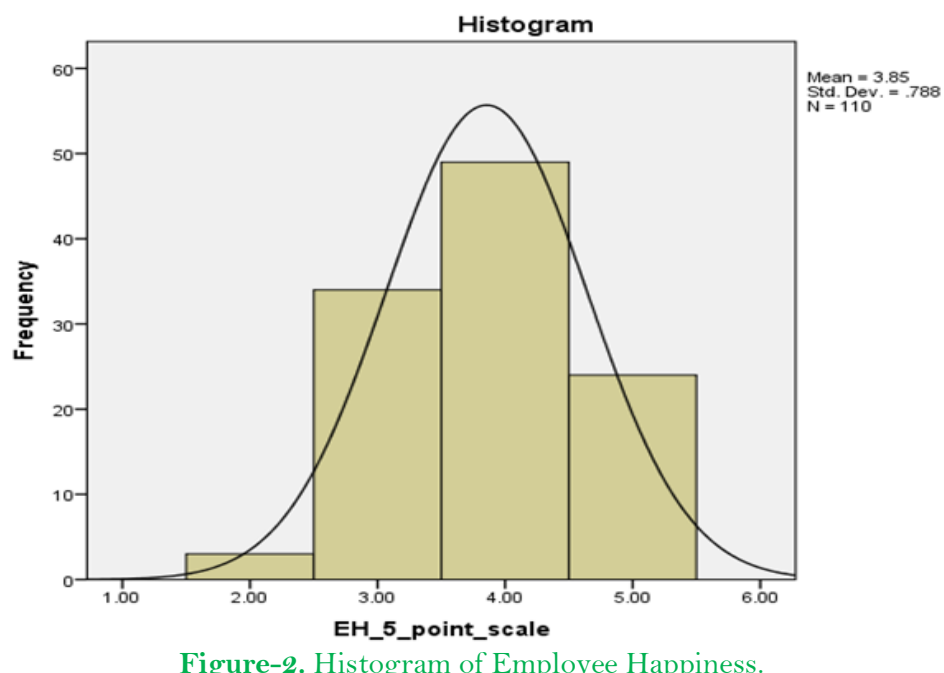

Figure-2. Histogram of Employee Happiness. 


\subsection{Human Resource Management}

According to the collected data from 110 Sri Lankan employees, Table 6 presents descriptive statistics of the independent variable of the study, i.e. Human Resource Management.

Table-6. Descriptive Statistics of HRM

\begin{tabular}{l|c}
\hline $\begin{array}{l}\text { Central Tendency and } \\
\text { Dispersion Measures }\end{array}$ & Value \\
\hline Mean & 4.1818 \\
\hline Median & 4.0000 \\
\hline Mode & 4.00 \\
\hline Standard Deviation & .74417 \\
\hline Variance & .554 \\
\hline Minimum & 2 \\
\hline Maximum & 5 \\
\hline Range & 3 \\
\hline
\end{tabular}

According to the Table 6 that gives the relevant measure of central tendency, i.e the mean, it is 4.1818 which means that majority of Sri Lankan employees under the study mentioned that practice of HRM in their organizations are in a high level. The standard deviation is .74 which is less than 1 . Hence the data dispersion from the mean value is not very much. Table 7 provides frequencies of HRM.

Table-7. Frequencies of HRM

\begin{tabular}{c|c|c|c|c}
\hline Value & Frequency & Percent & Valid Percent & Cumulative Percent \\
\hline Valid 2 & 1 & .9 & .9 & .9 \\
\hline 3 & 19 & 17.3 & 17.3 & 18.2 \\
\hline 4 & 49 & 44.5 & 44.5 & 62.7 \\
\hline 5 & 41 & 37.3 & 37.3 & 100.0 \\
\hline Total & 110 & 100.0 & 100.0 & \\
\hline
\end{tabular}

Table 7 presents mainly four rows: the first row that is for the composite response low level of HRM practices (coded in the data with the value 2), the second row that is for the composite response moderate level of HRM practices (coded in the data with the value 3), the third row for the composite response high level of HRM practices (coded with the value 4), and the fourth row for the composite response very high level of HRM practices (coded with the value 5). There are 19 employees who perceive that their organizations' HRM practices are in a moderate level and the percentage of such employees is 17.3. 49 employees have accepted that high degree of HRM practices being implemented by their organizations and as a percentage it is 44.5 which is the highest frequency while 41 employees have rated that the degree of HRM practice level is very high. Only 1 employee said that there is 'low level of HRM practices' and there are no employees who have mentioned that there is very low level of HRM practices in their organizations. As an overview we can say that more than half of Sri Lankan employees $(81.8 \%)$ consider that the HRM practice level of their organizations are in a high or very high level. The relevant histogram for the above results is depicted below in Figure 3.

Above analysis results answered the second research question of the study is: What is the degree of HRM level as per the perception of employees under study?

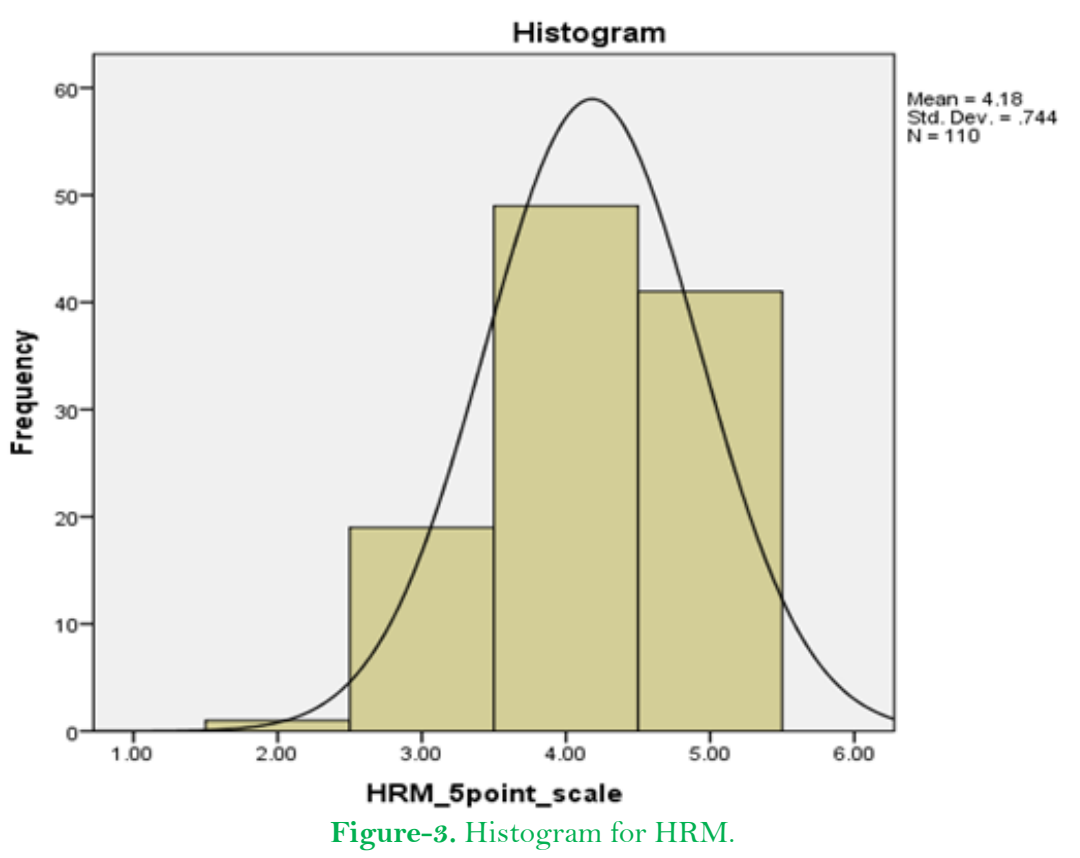

\subsection{Impact of HRM on Employee Happiness}

The third research question of the study is: Does HRM impact on employee happiness? Based on the empirical evidences in literature review and the researchers' logical beliefs an alternative hypothesis was formulated and it was: "There is a significant positive impact from HRM on employee happiness". Further, a theoretical framework was formulated based on the above hypothesis and literature review. In order to text the validity of the alternative hypothesis and the theoretical framework the Linear Regression Analysis was carried out. Table 8, 9, and 10 present the results of the linear regression analysis. 
Table-8. Model Summary.

\begin{tabular}{c|c|c|c|c}
\hline Model & R & R Square & Adjuster R Square & Std. Error of the Estimate \\
\hline 1 & .675 & .456 & .451 & 8.74729 \\
\hline
\end{tabular}

Table-9. ANOVA Table.

\begin{tabular}{cc|c|c|c|c|c}
\hline & Model & Sum of Squares & df & Mean Square & F & Sig. \\
\cline { 1 - 4 } 1 & Regression & 6918.082 & 1 & 6918.082 & \multirow{2}{*}{90.415} & \multirow{2}{*}{.000} \\
\cline { 1 - 3 } & Residual & 8263.636 & 108 & 76.515 & & \\
\cline { 1 - 3 } & Total & 15181.718 & 109 & & & \\
\hline
\end{tabular}

Table-10. Coefficients Table.

\begin{tabular}{c|c|c|c|c|c}
\hline \multirow{2}{*}{ Model } & \multicolumn{2}{|c|}{ Unstandardized Coefficients } & Standardized Coefficients & \multirow{2}{*}{ t } & Sig. \\
\cline { 2 - 5 } & B & Std. Error & Beta & & 1 \\
\hline 1 & (Constant) & 19.397 & 5.821 & .675 & \\
\hline & HRM & .772 & .081 & \\
\hline
\end{tabular}

According to the above analysis $\mathrm{R}$ square is .456 which means that 45.6 percent of variance in employee happiness is explained by human resource management. This positive impact is highly significant as sig. value is .000 and this value is less than .01. Thus, it is possible to accept the alternative hypothesis: "There is a significant positive impact from HRM on employee happiness". Therefore, there is statistical evidence to claim that HRM practices of an organization positively and significantly impact its employees' happiness. The relevant regression equation is, Employee Happiness $=19.397+.772 * \mathrm{HRM}$.

\section{Discussion}

Under descriptive statistics, it was found that majority of Sri Lankan employees under study had a high level of happiness. Furthermore, majority of Sri Lankan employees under study considered that the HRM practice level of their organizations is in a high level. This provides a positive sign that many organizations in Sri Lanka in which majority of employees under study are working, practice HRM functions in a way that keeps employees happy. However, there is still room for them to improve their HRM practices like welfare management, job design, induction and selection as many employees have rated those functions as moderate.

It was further identified that employee satisfaction is affected positively by HRM and this impact is highly significant. The major reason for this might be that many dimensions of happiness i.e. hedonic and eudaimonic are affected by HRM practices in the organization. for an example when the labor management relationships in the organization are very sound and when there are proper implementations of work life balance initiatives, this cause employees to maintain work life and family life happiness which are coming under dimensional life satisfaction of hedonic happiness. Another example is that HRM functions like training and development and performance evaluation ensures that employees are able to do something and they have done something meaningful through evaluations. This may also make employees happy under the dimension of eudaimonic. As an overall, HRM is contributing to employees' happiness through grievances handling. Grievance means any discontent or dissatisfaction arising from a feeling or a belief of injustice felt by an employee or a group of employees in connection with the work environment (Opatha, 1994). As concern for productivity is vital (Akuratiyagamage \& Opatha, 2004) contented or happy employees are integral to achieve high productivity for the organization.

\section{Conclusion}

Two important variables, i.e. HRM and employee happiness were considered in this study. Happiness of majority of Sri Lankan employees under the study and HRM practice level of those employees' organizations are high. It is statistically proved that HRM positively and significantly impact on employee happiness. Thus, it is recommended that any organization that wishes to enhance the happiness of employees, needs to properly execute their HRM functions with right policies and procedures.

\section{References}

Ahammad, T. (2017). Personnel management to human resource management (HRM): How HRM functions? Journal of Modern Accounting and Auditing, 13(9), 412-420.Available at: https://doi.org/10.17265/1548-6583/2017.09.004.

Akuratiyagamage, V. M., \& Opatha, H. (2004). Grievances of middle managers: An empirical investigation into perceptions of commercial bank branch managers in Sri Lanka. Journal of Management Research, 4(2), 99-112.

Anthonia, A. A., \& Omotayo, O. A. (2012). Human resource management: Theory \& practice. Lagos: Pumark Nigeria Limited.

Arachchige, B. J., \& Robertson, A. (2015). The effect of human resource management high performance work practices on organisational outcomes: A Sri Lankan perspective. Sri Lankan Journal of Human Resource Management, 5(1), 7-30.Available at: https://doi.org/10.4038/sljhrm.v5i1.5625.

Bataineh, A. K. (2019). Impact of work-life balance, happiness at work, on employee performance. International Business Research, 12(2), 99112.Available at: https://doi.org/10.5539/ibr.v12n2p99.

Biggs, D., Swailes, S., \& Baker, S. (2016). The measurement of worker relations: The development of a three-component scale. Leadership \& Organization Development Journal, 37(1), 1-12.

Blackman, D., O'Flynn, J., \& Mishra, D. (2010). Can strategic human resource management enable gross national happiness? International Journal of Commerce E゚ Management, 20(3), 232-245.Available at: https://doi.org/10.1108/10569211011076929.

Chaubey, D. S., \& Rawat, B. (2016). Analysis of labour welfare schemes and its impact on job satisfaction: An empirical study. Management Convergence, 7(2), 45-53.

Demo, G., Neiva, E. R., Nunes, I., \& Rozzett, K. (2012). Human resources management policies and practices scale (HRMPPS): Exploratory and confirmatory factor analysis. BAR-Brazilian Administration Review, 9(4), 395-420.Available at: https://doi.org/10.1590/s 180776922012005000006.

Eneh, S. I., \& Awara, N. F. (2016). Strategic human resource management practices and organizational growth: A theoretical perspective. Global Journal of Social Sciences, 15(1), 27-37.Available at: https://doi.org/10.4314/gjss.v 15i1.3.

Gomathi, S. (2014). A study on grievance management in improving employee performance in a Pvt Enterprise. Mediterranean Journal of Social Sciences, 5(20), 20-29.

Guest, D. E. (1987). Human resource management and industrial relations. Journal of Management Studies, 24(5), $503-521$. 
Guthrie, V. M. J. (2012). Management control of work-life balance. A narrative study of an Australian financial institution. Journal of Human Resource Costing \& Accounting, 16(4), 258-280.

Hills, P., \& Argyle, M. (2002). The Oxford happiness questionnaire: A compact scale for the measurement of psychological well-being. Personality and Individual Differences, 33(7), 1073-1082.

Hirschi, A., Freund, P. A., \& Herrmann, A. (2013). The career engagement scale: Development and validation of a measure of proactive career behaviors. Journal of Career Assessment, 22(4), 575-594.

Huta, V., Pelletier, L. G., Baxter, D., \& Thompson, A. (2012). How eudaimonic and hedonic motives relate to the well-being of close others. The Journal of Positive Psychology, 7(5), 399-404.Available at: https://doi.org/10.1080/17439760.2012.705318.

Itang. (2015). Work discipline and work competence with quality of service in the office of religious affairs (KUA) District of Mount Kencana Lebak Regency of Banten. Journal Management \& Sustainability, 5, 132-138.Available at: https://doi.org/10.5539/jms.v5n3p132.

Itika, J. (2011). Fundamentals of human resource management: Emerging experiences from Africa. African Public Administration and Management Eeries, 4(13), 459-468.

Joo, B. K., \& Lee, I. (2017). Workplace happiness: Work engagement, career satisfaction, and subjective well being. Evidence Based HRM: $A$ Global Forum for Empirical Scholarship, 5(2), 206-221.

Kaczmarek, L. D. (2017). Happiness, in Zeigler-Hill, Virgil, Shackelford, Todd K. (Eds.), Encyclopedia of Personality and Individual Differences. Netherlands: Springer Publishers.

Kottawatta, H. (2015). Measuring HRM practices. HRM Scintilla: HRM Review, 5(1), 1-27.

Kowalskia, T. H. P., \& Lorettob, W. (2017). Well-being and HRM in the changing workplace. The International Journal of Human Resource Management, 28(16), 2229-2255.

Lyubomirsky, S., \& Lepper, H. S. (1999). A measure of subjective happiness: Preliminary reliability and construct validation. Social Indicators Research, 46(2), 137-155.

Mabaso, C. M. (2012). The effectiveness of an induction program for newly appointed staff at Coastal Kzn Fet College. Thesis, Durban University of Technology.

Maleka, M. J., Swarts, I., \& Mmako, M. (2018). Happiness index for human resource management practitioners associated with the professional body. Journal of Economics and Behavioral Studies, 10(5), 297-305.Available at: https://doi.org/10.22610/jebs.v10i5(j).2518.

Marescaux, E., Winne, S. D., \& Forrier, A. (2018). Developmental HRM, employee well-being and performance: The moderating role of developing leadership. European Management Review, 16(2), 317-331.

Obedgiu, V. (2017). Human resource management, historical perspectives, evolution and professional development. Journal of Management Development, 36(8), 986-990.Available at: https://doi.org/10.1108/jmd-12-2016-0267.

Opatha, H. (1994). Employee grievance settlement procedure: A case study of two corporations. Management Review, 1(2), 53-60.

Opatha, H. H. D. N. P. (2019). Sustainable human resource management. Sri Lanka: Author.

Opatha, H. H. D. N. P. (2009). Human resource management: Personnel. Sri Lanka: Author.

Opatha, H. H. D. P. J., \& Opatha, H. H. D. N. P. (2020). Assertiveness and its relationship with self esteem: An empirical study of senior managers in a Sri Lankan Bank. Asian Journal of Social Sciences and Management Technology, 2(2), 52-60.

Perera, G. D. N. (2019). Occupational health and safety practice and job performance: Role of job satisfaction. Sri Lankan Journal of Human Resource Management, 9(1), 1-10.

Sankar, J. (2019). Employee satisfaction and customer satisfaction - A close comparison. International Journal of Business and Management Invention, 8(3), 24-29.

Seligman, M. (2011). What is well-being?, Excerpt from Flourish: A Visionary New Understanding of Happiness and Well Being. Retrieved from: https://www.authentichappiness.sas.upenn.edu/learn/wellbeing. [Accessed 02/04/2020].

Shen, J. (2010). Employees' satisfaction with HRM in Chinese privately owned enterprises. Asia Pacific Business Review, 16(3), 339354.Available at: https://doi.org/10.1080/13602380902846659.

Storey, J. (2007). Human resource management: A critical text. London: Thomson Learning.

Tubey, R., Rotich, K., \& Kurgat, A. (2015). History, Evolution and development of human Resource management: A contemporary perspective. European Journal of Business and Management, 7(9), 139-149.

Veenhoven, R. (2017). Measures of happiness: Which to choose?, in Gaël Brulé \&̊ Filomena Maggino (Eds.), Metrics of Well-being: Springer Publishing.

Veenhoven, R. (2012). Happiness: Also known as 'life-satisfaction' and 'subjective well-being, in Kenneth C. Land, Alex C. Michalos, and M. Joseph Sirgy (Eds.), Handbook of social indicators and quality of life research (pp. 63-77). Netherlands: Springer Publishers.

Wilton, N. (2016). An introduction to human resource management. London: Sage Publications Ltd.

Zamanana, M. S., Alkhaldia, M. H., Almajrouba, A. S., Alajmia, A. S., Alshammaria, J. M., \& Aburumman, O. J. (2020). The influence of HRM practices and employees' satisfaction on intention to leave. Management Science Letters, 1O(8), 1887-1894.

Zižek, S. S., Potočnik, A., \& Vaner, M. (2012). Employees well-being based on integrative and innovative model of HRM. Annals of the Alexandru Ioan Cuza University-Economics, 59(2), 231-250.Available at: https://doi.org/10.2478/v10316-012-0044-3. 